\title{
Status, habitat and conservation of the Rufous-fronted Antthrush Formicarius rufifrons
}

\author{
ANDREW W. KRATTER
}

\begin{abstract}
Summary
Habitat preferences of the Rufous-fronted Antthrush Formicarius rufifrons were studied along the Rio Tambopata in south-eastern Peru. All territories of this threatened species, endemic to lowland forests in the department of Madre de Dios, Peru, contained the near-juxtaposition of two distinct vegetation types: tall floodplain forest with shaded understorey, and more open, second-growth vegetation with a very dense layer of vegetation close to the ground. The latter habitat type was closely associated with disturbances, such as river erosion, tree falls, or human clearings. Two measures of antthrush density were calculated for the study area. A satellite photograph was used to identify appropriate habitat along the upper Río Tambopata, and using the antthrush density figures, a population size of 100-500 pairs was estimated for this area. This estimate was then used to calculate a global population of $700-3,500$ pairs. Approximately $20 \%$ of the global population occurs within currently protected areas. The habitat and diet of this species are discussed in relation to two other congeners.
\end{abstract}

Las preferencias de hábitat de Fomicarius rufifrons fueron estudiadas a lo largo del Río Tambopata en el sureste del Perú. Los territorios de esta amenazada especie, endémica de los bosques tropicales en el depto. de Madre de Dios, están compuestos por dos formaciones vegetales distintas: bosque alto de llanura y vegetación secundaria con un estrato inferior tupido. La vegetación secundaria se debe a los trastornos ecológicos, tales como la erosión fluvial, las caídas de árboles, y también a la tala de bosques. Los límites inferior y superior de densidad (tasa de población) fueron calculados en el área de estudio; los hábitats apropriados se identificaron a lo largo del río a través de imágenes de satélite y se pudo calcular un total de 100-500 parejas para la zona. Se empleó la tasa poblacional, entonces, para calcular la supuesta población global de 700-3,500 parejas. Hoy en día, aproximadamente $20 \%$ de la población global de la especie ocurre dentro de áreas protegidas. Se trata, además, el hábitat y la dieta de F. rufifrons en relación a dos especies congenéricas.

\section{Introduction}

The Rufous-fronted Antthrush Formicarius rufifrons has one of the smallest geographic ranges of any Amazonian bird species. All known sites for this species are in lowland forests in depto. Madre de Dios, Peru, along southern and western tributaries to the Río Madre de Dios, a total area of only $9,000 \mathrm{~km}^{2}$ 


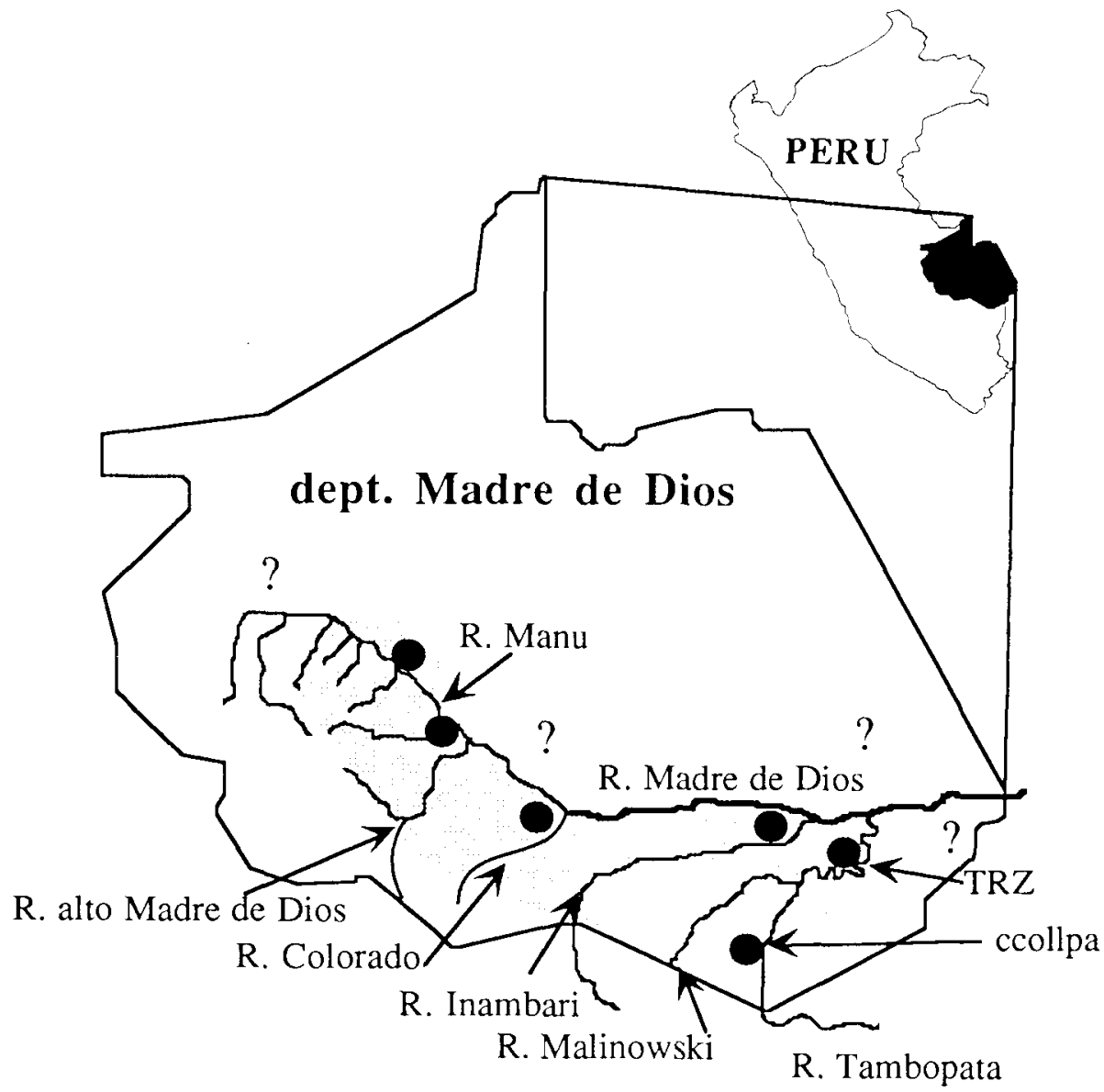

Figure 1. Distribution of the Rufous-fronted Antthrush. Solid circles are known locations for the species (as per Collar et al. 1992); shaded area is likely range; areas with question marks have not been adequately surveyed.

(Figure 1). It was not detected until 1954, when two were collected by C. Kalinowski at the mouth of the Río Colorado (Blake 1957). Two more were collected by Blake in 1958, one at the type locality and another at the mouth of the Rio Inambari (specimens at Field Museum Natural History and American Museum of Natural History, respectively). For the next 24 years it remained unrecorded, but was rediscovered in 1982 in Manu National Park (Parker 1983). There are only a handful of records since, all from the Manu National Park area or the Río Tambopata (Collar et al. 1992). Within its limited distribution, the anthrush is apparently restricted to river-edge habitats along large rivers, although it is rare even within this specialized habitat (Collar et al. 1992). The limited distribution, habitat specificity, and low population density of the Rufous-fronted Antthrush led it to be ranked as a "vulnerable" in the latest Red Data Book (Collar et al. 1992), which provided notes on its natural history and conservation status. 
Table 1. Study-site characteristics (see text for site names)

\begin{tabular}{|c|c|c|c|c|c|c|c|c|c|c|}
\hline \multirow[t]{2}{*}{ Site } & \multirow[t]{2}{*}{ Dates surveyed } & \multirow[t]{2}{*}{$\begin{array}{l}\text { Relative } \\
\text { elevation }\end{array}$} & \multicolumn{4}{|c|}{$\begin{array}{l}\text { Length }(\mathrm{km}) \text { of shoreline } \\
\text { surveyed by habitat }^{1}\end{array}$} & \multicolumn{4}{|c|}{$\begin{array}{c}\text { Area (ha) of habitats } \\
\text { surveyed }^{1}\end{array}$} \\
\hline & & & Total & $\mathrm{F}$ & $\mathrm{B}$ & $E$ & Total & $\mathrm{F}$ & $\mathrm{B}$ & $\mathrm{E}$ \\
\hline 1 & 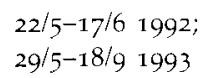 & high, low & $4 \cdot 1$ & 2.4 & 1.8 & 1.0 & 138.8 & 81.1 & $47 \cdot 2$ & 11.9 \\
\hline 2 & $31 / 5-7 / 61993$ & low & 0.6 & 0.3 & o & 0.3 & 11.2 & 3.0 & o & 8.2 \\
\hline 3 & $8-17 / 6 \quad 1993$ & high & 0.8 & 0 & 0.8 & o & 14.2 & 8.5 & 5.2 & 0.5 \\
\hline 4 & $18-23 / 6 \quad 1993$ & high, low & 0.6 & 0 & 0.4 & 0.2 & 10.2 & o & 8.8 & 1.9 \\
\hline 5 & $22-27 / 6 \quad 1993$ & low & 0.4 & 0 & 0 & 0.4 & 8.6 & 0 & o & 8.6 \\
\hline 6 & $\begin{array}{l}18 / 7-3 / 81992 \\
15-22 / 81993\end{array}$ & high, low & 1.0 & 1.0 & o & 0 & $\mathrm{n} / \mathrm{a}$ & $\mathrm{n} / \mathrm{a}$ & $\mathrm{n} / \mathrm{a}$ & $\mathrm{n} / \mathrm{a}$ \\
\hline Total & & & 6.5 & 2.7 & 3.2 & 1.9 & 183.0 & 92.6 & 61.2 & 31.1 \\
\hline
\end{tabular}

${ }^{1} \mathrm{~F}$, Floodplain forest, B, Bamboo, and E, Early successional vegetation. Habitat types may add up to more than total because more than one habitat may be sampled at one location.

? does not include site 6 .

Most of the information available on the Rufous-fronted Antthrush is based on observations of solitary individuals and pairs (Parker 1983, Collar et al. 1992). In this paper I examine the natural history of the Rufous-fronted Antthrush along the Rio Tambopata, where I found a relatively large population. The study includes an analysis of the habitat requirements, using a number of territories, and estimates of the total population on the Tambopata and global population. Also included is an analysis of this species's diet. This research was conducted while I was studying habitat selection and foraging ecology of avian bamboo specialists.

\section{Study sites}

My main study site ( $\operatorname{site} 1$ ) was the Ccollpa de Guacamayos (= ccollpa, the local Indian word for river banks where macaws and parrots gather to eat clay soil), on the west bank of the Río Tambopata, $75 \mathrm{~km}$ south-south-west of Puerto Maldonado, depto. Madre de Dios, Peru (Figure 1). The ccollpa study site is dominated by an extensive stand of bamboo (Bambusa [Guadua] weberbaueri) that stretches for $2.5 \mathrm{~km}$ along a 50-m tall bluff over the Río Tambopata and a small tributary stream, and then for approximately $10 \mathrm{~km}$ inland along similar high-elevation soils. In the northern part of this study site, the ground is approximately $3 \mathrm{~m}$ above normal high-water level on the Tambopata, and tall floodplain forest dominates. This forest probably floods every few years (E. Nycander V., pers. comm.). Bamboo stands are common in this forest, primarily in tree-fall gaps and along slightly lower elevation soils that probably flood more regularly. The vegetation at the ccollpa study site is described in more detail in Foster et al. (1994).

Four other peripheral study sites (Table 1) with the same species of bamboo near the ccollpa were also surveyed: site 2 ( $2 \mathrm{~km}$ north-east of the ccollpa), a small bamboo stand with dense Heliconia stretching for approximately $600 \mathrm{~m}$ along the east bank of the Río Tambopata; site 3 ( $3 \mathrm{~km}$ south of the ccollpa), a $800 \mathrm{~m}$ long riverside bamboo stand along the west bank of the Río Tambopata; 
site 4 ( $8 \mathrm{~km}$ south of the ccollpa), an extensive bamboo stand, composed of dense, large-diameter bamboo on the west bank of the Rio Tambopata; and site $5(2.5 \mathrm{~km}$ south-south-east of the ccollpa), a $600 \mathrm{~m}$ long, early successional bamboo stand with some Heliconia and wild bananas along the east bank of the Tambopata (Figure 2).

The lowland portion of the Río Tambopata has two physiographically distinct sections. Between the mouth of the Tambopata at Puerto Maldonado and the mouth of the Río Malinowski (Figure 1), the river channel is narrow (c.200 m wide) and deep; vegetated river islands are absent; tall floodplain forest generally extends to the edges of the river channel. Upstream from the Rio Malinowski the river changes to a $1.7-15 \mathrm{~km}$ wide river channel, with a $200-$ $900 \mathrm{~m}$ wide main channel, numerous smaller channels, and many vegetated river islands; the river is bordered in many sections by early, primary successional vegetation (Figure 2). A few sections along the upper part of the river have extensive stands of bamboo atop $30 \mathrm{~m}$ bluffs, but most river-edge is only a few metres above normal high water, and probably floods every few years. Sites $1-5$ were in the upper section.

In both 1992 and 1993, I also visited a sixth site, the 5,000 ha Explorer's Inn Reserve (EIR: see Foster et al. 1994), at the mouth of the Rio La Torre on the east bank of the lower Río Tambopata (Figure 1). At least one Rufous-fronted Antthrush was briefly present across from the EIR on the west bank of the Tambopata in 1988 (Collar et al. 1992), but it has not been recorded since in this well-studied area. The vegetation of the EIR is described in Erwin (1984).

\section{Methods}

At least $1 \mathrm{~km}$ of trail was cut at each study site; the main ccollpa site had over $15 \mathrm{~km}$ of already-cut trails and the EIR had over $25 \mathrm{~km}$ of trails. The trails at sites 2-5 were cut to survey birds in bamboo habitats, but also included portions of forested habitats without bamboo. The majority of each trail system paralleled the river at sites 2-5 (Table 1). Singing Rufous-fronted Anthrushes were opportunistically encountered while slowly walking the trails at all sites during 180 days of field observation in 1992-1993.

\section{Habitat}

The vegetation at sites 2-5 was quantified along a $30 \times 1 \mathrm{~m}$ vegetation transect randomly placed within each $100 \mathrm{~m}$ section of trail at each site. For example, the $1,300 \mathrm{~m}$ of trail at site 3 had 13 such transects. Vegetation transects were randomly placed along two and three $1,000 \mathrm{~m}$ stretches of trail in the same manner at sites 1 and 6, respectively. The following variables were measured on each transect: the number of (1) bamboo stems, (2) Heliconia stems, and (3) non-bamboo stems $>3 \mathrm{~cm} \mathrm{DBH}$; the diameter of each (4) bamboo and (5) non-bamboo stem (all Heliconia stems were $3-4 \mathrm{~cm}$ ); the (6) percent cover bamboo; (7) average height of bamboo; and (8) average canopy height. The correlation matrix of standardized variables was used to reduce the variation in the matrix to a few axes using Principal Component Analysis (PCA). The complete data matrix for the habitat variables is available from the author. 

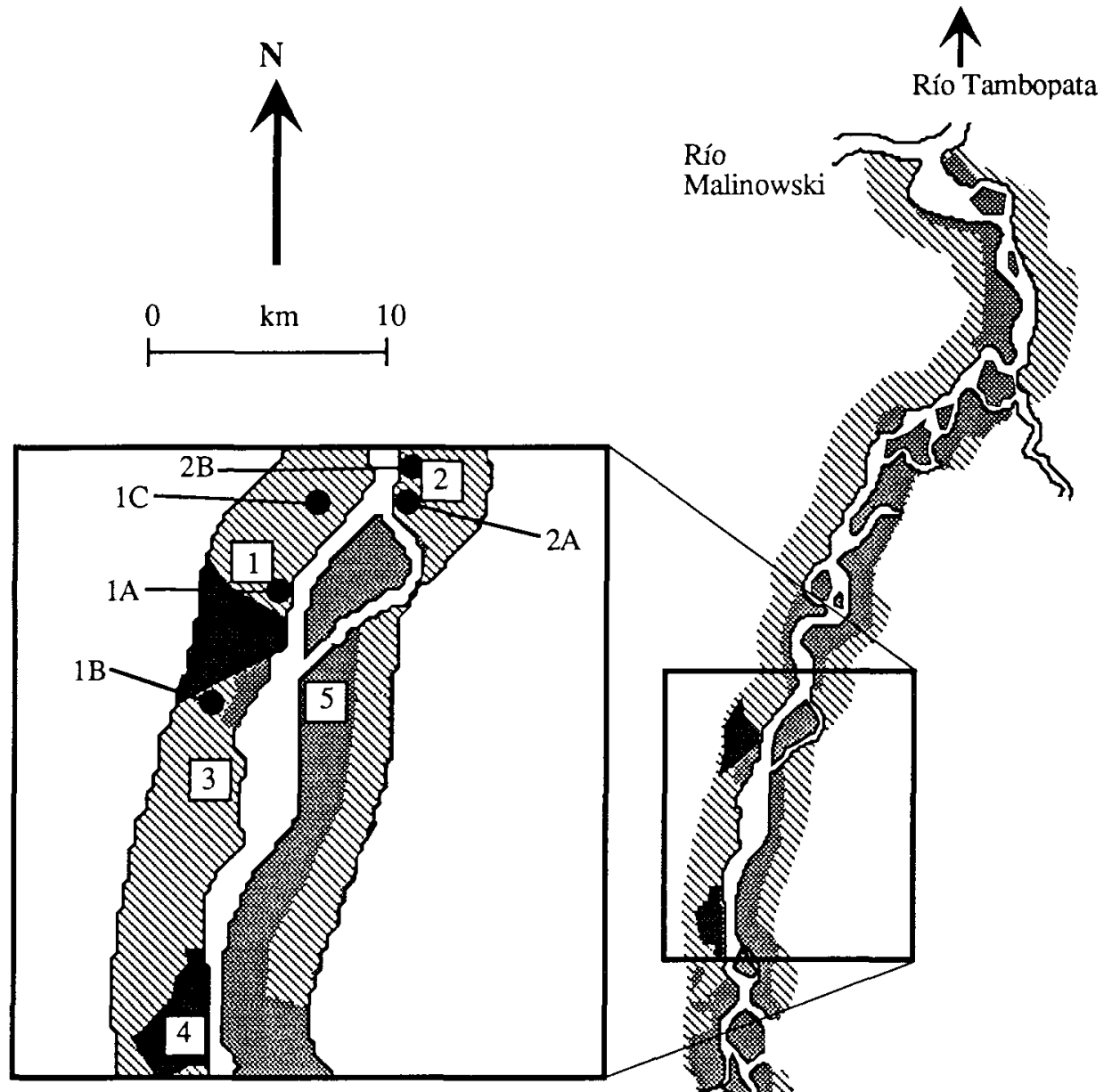

mature floodplain forest

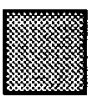

early successional vegetation

bamboo thickets

Figure 2. Habitat types and the location of study sites and territories along the upper Río Tambopata. Distributions of habitat types are based on satellite imagery and personal observation. Habitats are only shown within $1.5 \mathrm{~km}$ of the main channel. Numbers in squares represent study sites $1-5$; solid circles represent location of Rufous-fronted Antthrush territories. 


\section{Tambopata population}

Antthrush density was measured in two ways: (1) the number of territories per linear length of each river-edge habitat surveyed, and (2) the number of territories per area for each habitat surveyed, assuming that 1 ha of area is surveyed for each $100 \mathrm{~m}$ of trail. For measure 1 , only one territory is assumed to occur for each unit length of river-edge, or, in other words, the species density is only one territory deep extending inland away from the river. This is probably true at most sites; however, in more favourable situations, territories may be more than one deep (e.g. near Manu Lodge: S. Hilty in litt. 1994). For both measures, a total estimate was also calculated, without differentiating by habitat.

The locations of territories were identified on a satellite photograph that includes all of the lower Río Tambopata (Earth Observation Satellite Company 1991). The following general habitat types along the Rio Tambopata can be distinguished in the photograph: (1) tall floodplain forest, (2) bamboo, and (3) early successional vegetation (Gynerium, Cecropia). Only habitat patches exceeding 2 ha in area are discernible on the photograph.

Using the satellite photograph, the total amount (either linear river-edge length or $\mathrm{km}^{2}$ of floodplain habitat) of each type of river-edge habitat was measured for the Rio Tambopata between the mouths of the ríos Malinowski and Távara (see Figure 2). Using the density estimates computed for the sites surveyed, an estimate of the total population along the Río Tambopata was then calculated.

\section{Diet}

A male and female Rufous-fronted Antthrush were collected in 1992 (one specimen each at Louisiana State University Museum of Natural Science (LSUMZ) and Museo de Historia Natural Javier Prado de la Universidad Nacional Mayor de San Marcos in Lima, Peru); these are only the fifth and sixth specimens for this species (Collar et al. 1992). Tissue samples (in alcohol) of each specimen are at LSUMZ for genetic analysis. Tape-recordings were also made of the species at the ccollpa study site. Stomachs were immediately removed from each specimen and placed in a vial with $70 \%$ ethanol. Contents were examined and identified using a 6-25 $\times$ dissecting microscope. The stomach contents were compared with those from the sympatric Black-faced and Rufous-capped Antthrushes (Formicarius analis and F. colma, respectively) from the LSUMZ stomach content collection. The stomachs of the other antthrush species were collected in northern Bolivia or eastern Peru.

\section{Results}

At least five individual territories of the Rufous-fronted Antthrush were found at the ccollpa and at site 2 (Figure 2). All territories were within 1,200 $\mathrm{m}$ of the Río Tambopata. No Rufous-fronted Antthrushes were recorded at sites 3-6. Most river-edge vegetation across from the EIR (site 6) where the Rufous-fronted Antthrush was recorded in 1988 (Collar et al. 1992, K. V. Rosenberg pers. 
comm.) has been seriously degraded by recent human colonization along the lower Río Tambopata (pers. obs., see below).

\section{Habitat}

The three territories at the ccollpa (site 1) were all in the floodplain forest and were not on the bamboo-laden bluff, except a probable wanderer from a nearby territory (see below). Territory $1 \mathrm{~A}$, near the ccollpa lodge, was the most intensively studied of the five territories. A pair here in 1992 was collected after being recorded for 18 consecutive days, but the territory had been recolonized by at least one other bird by the time I returned to the site in 1993. These birds were very vocal, singing every day from about an hour after sunrise until noon, and again intermittently in the afternoon. The birds generally kept within $50 \mathrm{~m}$ of the lodge clearing, where dense herbaceous vegetation and woody bamboo had invaded the forest edge. The clearing was surrounded on three sides by older floodplain forest, with open shaded understorey; a dense bamboo stand was on the west side. The birds were never recorded in the nearby river-edge scrub nor the Gynerimm thickets that border the beach only $75 \mathrm{~m}$ to the east.

Territory $1 \mathrm{~B}$ at the ccollpa site was also just peripheral to the main bamboo stand (Figure 2). It could not be reached from the trail system, but birds were regularly heard singing in this area in 1993. The territory was on an approximately 5 ha peninsula of older floodplain forest, cut off from the main site bluff by a $10 \mathrm{~m}$ wide quebrada (stream) that runs into the Río Tambopata. This peninsula of mature forest, bordered on three sides by dense bamboo and other river-edge vegetation, is only a few metres above the normal high water of the river and probably floods regularly. On 22 May 1992, one bird, presumably from this territory, was singing about $50 \mathrm{~m}$ north-east of its usual location, on top of the bamboo-covered bluff along trail Ai.

The third territory (1C) was not found until 1 September 1993, when I first visited the area approximately $2.5 \mathrm{~km}$ north of the lodge (Figure 2). This territory was also in low-elevation floodplain forest, but bordered a large bamboo stand. A recent tree fall at the forest edge had resulted in a thick understorey of bamboo and herbaceous vegetation.

Another bird was heard singing three times over a lo-day period along a well-studied trail at site 1 ; this is not included as a territory, because the bird was not recorded here either before or after these encounters. The bird was in an area similar to the above territory: low-elevation floodplain forest, at the edge of a large bamboo stand, but even further inland $(1,300 \mathrm{~m})$ than $1 \mathrm{C}$.

The other two territories $(2 \mathrm{~A}, 2 \mathrm{~B})$ were at site 2 , on the east bank of the Tambopata, $2 \mathrm{~km}$ north of the ccollpa (Figure 2 ). Both territories were in small (c. 2 ha) patches of mature floodplain forest with shaded open understorey, bordered by dense stands of Heliconia and bamboo. These are the first records of this species from the east bank of the Río Tambopata.

Only the two territories at site $2(2 \mathrm{~A}$ and $2 \mathrm{~B})$ fell within the vegetation transects for the sites. The mean scores over all transects at each site were plotted for PCA1 and $\mathrm{PCA} 2$ (35\% and $22 \%$ of the variation, respectively) 


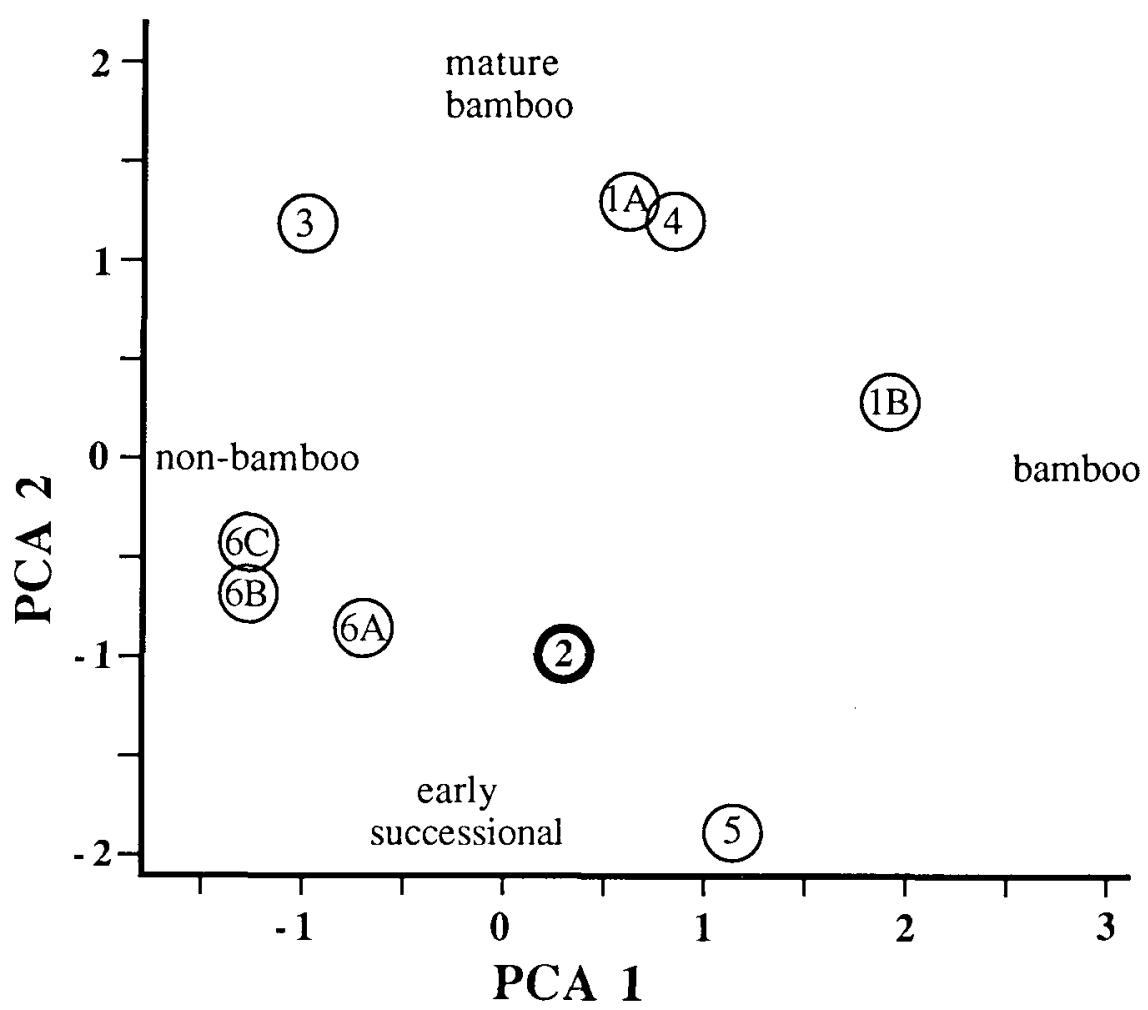

Figure 3. Plot of first two axes of ordination of habitat variables of study sites using Principal Component Analysis. Sites 1 and 6 had more than one set of transects (see text); only site 2 (bold type) had Rufous-fronted Antthrush territories.

(Figure 3). Site 2 showed an intermediate score for PCA1, which had high positive loadings for number of bamboo stems and percent bamboo cover, and high negative loadings for number of non-bamboo stems and canopy cover. PCAI thus shows, in general, how much each site was dominated by bamboo. The intermediate value of site 2 probably reflected both the presence of older forest without much bamboo (negative score) and dense understorey with bamboo (positive score) at the site. Site 2 had a negative score on PCA2, which had high positive loadings for bamboo height and size of bamboo stems and high negative loadings for number of Heliconia stems. PCA2 thus appeared to measure the degree of recent disturbance; sites (e.g. 2 and 5) with dense Heliconia and small diameter bamboo, which are associated with recent disturbance, had negative scores.

Sites without Rufous-fronted Antthrushes either lacked recent disturbance (sites 3 and 4 , the two sets of transects at the ccollpa), were dominated by tall shady forest (the three sets of transects at EIR), or were composed only of vegetation associated with recent disturbance (site 5). All five territories shared the near juxtaposition of two habitats: dense undergrowth, associated with recent disturbance, and tall floodplain forest with open understorey. 
Table 2. Estimate of number of Rufous-fronted Antthrush territories on upper Río Tambopata using density calculated by linear length of river habitats surveyed.

\begin{tabular}{lccccc}
\hline Habitat type & Territories & $\begin{array}{c}\text { River edge } \\
\text { surveyed }(\mathrm{km})\end{array}$ & $\begin{array}{c}\text { Density } \\
(\mathrm{terr} / \mathrm{km})\end{array}$ & $\begin{array}{c}\text { Total habitat } \\
(\mathrm{km})\end{array}$ & $\begin{array}{c}\text { Total } \\
\text { territories }\end{array}$ \\
\hline Forest & 5 & 2.7 & 1.85 & 45.9 & 84.9 \\
Bamboo & 0 & 3.2 & 0 & 4.9 & 0 \\
Early succession & 0 & 1.9 & 0 & 61.6 & 0 \\
Total & 5 & 6.5 & 0.77 & $\mathbf{1 1 2 . 4}$ & 86.5 \\
\hline
\end{tabular}

\section{Tambopata population}

On the satellite photograph, the common denominator of all Rufous-fronted Antthrush territories (see Figure 2) is the occurrence of older floodplain forest near the river, where either dense Heliconia or bamboo is found. This proximity creates the requisite mosaic of tall shady forest and dense understorey that this species apparently prefers. The estimated population size along the Río Tambopata could only be calculated between the ríos Malinowski and Távara because density could not be computed for the physiographically different river system downstream from the Malinowski (see above). Only habitats within $1.5 \mathrm{~km}$ of the main channel of the Tambopata were measured, because no territories were found farther inland than this.

The total number of territories along the Río Tambopata differed quite dramatically between the two measures of density (Tables 2 and 3); the estimated number of territories per linear kilometre of river was only $17 \%$ of that by area.

\section{Diet}

The diet of the Rufous-fronted Antthrush consists almost entirely of insects, although parts of snail shells (Gastropoda, Mollusca) were found in both stomachs examined, and centipedes (Chilopoda, Arthropoda) were present in one (Table 4). Although the samples of stomachs are too small for statistical analyses, a general similarity among the three Formicarius species is evident. The diet of all three species was dominated primarily by wingless ants (Formicidae) and secondarily by orthopterans. Beetle remains also were evident in the diet of all three species. Membranous wings were nearly absent from all stomachs, indicating that highly mobile flying insects (e.g. Diptera and Hymenoptera, apart from ants) are not important in the diet of these species.

Table 3. Estimate of number of Rufous-fronted Antthrush territories on upper Río Tambopata using densities calculated by total area of river habitats surveyed.

\begin{tabular}{lccccc}
\hline Habitat type & Territories & $\begin{array}{c}\text { Area surveyed } \\
\left(\mathrm{km}^{2}\right)\end{array}$ & $\begin{array}{c}\text { Density } \\
\left(\text { terr } / \mathrm{km}^{2}\right)\end{array}$ & $\begin{array}{c}\text { Total area } \\
\left(\mathrm{km}^{2}\right)\end{array}$ & $\begin{array}{c}\text { Total } \\
\text { territories }\end{array}$ \\
\hline Forest & 5 & 0.926 & 5.4 & 93.8 & 506.5 \\
Bamboo & 0 & 0.612 & 0 & 5.9 & 0 \\
Early succession & 0 & 0.311 & 0 & 91.9 & 0 \\
Total & 5 & 1.849 & 2.7 & 190.8 & 515.2 \\
\hline
\end{tabular}


Table 4. Diet of Formicarius antthrushes. The minimum number of individuals for each prey taxon is given for each $F$, rufifrons stomach. The average number and percentage of total for each prey taxon are given for all three species.

\begin{tabular}{lcccccccc}
\hline Prey taxon & \multicolumn{3}{c}{$\begin{array}{c}\text { F. rufifrons } \\
\mathrm{n}=2\end{array}$} & \multicolumn{2}{c}{$\begin{array}{c}\text { F. mnalis } \\
\mathrm{n}=3\end{array}$} & \multicolumn{2}{c}{$\begin{array}{c}\text { F. colma } \\
\mathrm{n}=3\end{array}$} \\
& male & female & $\overline{\mathrm{x}}$ & $\%$ & $\overline{\mathrm{x}}$ & $\%$ & $\overline{\mathrm{x}}$ & $\%$ \\
\hline Gastropoda & 4 & 3 & 3.5 & 8 & 0.7 & 2 & 0 & 0 \\
Chilopoda & 2 & 0 & 1 & 2 & 0 & 0 & 0 & 0 \\
Arachnida & 0 & 0 & 0 & 0 & 1 & 3 & 1.7 & 2 \\
Orthoptera & 24 & 1 & 12.5 & 30 & 3.7 & 10 & $19 \cdot 3$ & 26 \\
Isoptera & 6 & 0 & 3 & 7 & 0 & 0 & 0 & 0 \\
Coleoptera & 3 & 5 & 4 & 10 & 2 & 6 & 6 & 8 \\
Cucurlionidae & 0 & 1 & 0.5 & 1 & 0.3 & 1 & 0 & 0 \\
Coleoptera larvae & 0 & 0 & 0 & 0 & 1 & 3 & 0 & 0 \\
Lepidoptera (larvae) & 0 & 2 & 1 & 2 & 2 & 6 & 0 & 0 \\
Hymenoptera & 0 & 0 & 0 & 0 & 0.3 & 1 & 0 & 0 \\
Formicidae & 18 & 14 & 16 & 39 & 24.7 & 69 & $47 \cdot 7$ & 64 \\
prey items/stomach & 57 & 26 & 17 & 38 & 50 & 82 & 17 & 124 \\
\hline
\end{tabular}

\section{Discussion}

Specialization on river-edge habitats is widespread in Amazonian birds (Remsen and Parker 1983), including many species in south-eastern Peru. Certain other bird species that share the restricted distribution of the Rufous-fronted Antthrush are also river-edge specialists (Collar et al. 1992: 691).

The five Rufous-fronted Antthrush territories studied on the upper Río Tambopata had a shared feature: a thick understorey layer, $1 \mathrm{~m}$ or less above the ground, was present in or at the edge of tall floodplain forest within $1.2 \mathrm{~km}$ of the Río Tambopata. Analyses of habitat using the satellite photograph also confirmed that all antthrush territories occurred where floodplain forest was near to the river. However, dense undergrowth is limited within older floodplain forests and is mostly restricted to the edges of disturbances (tree falls and river-edges) where the understorey is open to the sky. The Rufous-fronted Antthrush appears to need both the dense undergrowth of gaps created by disturbances, and the open, shaded understorey of more mature forest. Rufous-fronted Antthrush territories from other parts of its range also share these habitat features (Parker 1983, Collar et al. 1992). Although all territories studied in the ccollpa area included or bordered bamboo stands, the presence of bamboo is not a requisite for territories (e.g. at Manu Lodge: S. Hilty in litt. 1994).

Although drawing conclusions from such a small number of territories must be regarded as tentative, the areas where the antthrush was missing might be more informative. Contrary to Collar et al. (1992), Rufous-fronted Antthrushes were absent from nearly pure stands of bamboo, such as those that characterize the higher elevation bluffs at sites 1,3 , and 4 . Instead, the birds appeared to prefer the periphery of bamboo thickets in low-elevation situations, where canopy cover was greater and the forest floor was shaded. Rufous-fronted Antthrushes were also absent from both the interior of mature floodplain forest and from dense, early successional river-edge vegetation without older forest, 
such as at site 5 or on the large vegetated island across the Rio Tambopata from the ccollpa lodge (Figure 2). This island, dominated by early successional vegetation (e.g. Gynerium, Cecropia, Salix, and Tessaria), was visited five times in 1992-1993. Other bird species on the island with voices no stronger than the antthrush (e.g. Black-throated Antbird Myrmeciza atrothorax) could be heard from the lodge side of the river, which was visited daily.

Along the lower part of the Río Tambopata, downstream from the Río Malinowski, tall forest extends close to the river channel for most of its length. This proximity of forest and edge should create the requisite habitat for the Rufous-fronted Antthrush, but there is only the one record for the species on this lower section of river (see above), and the area in and near the EIR has been studied intensively for over 15 years. This individual was only detected here for three months. This paucity of records may be related to the frequency of disturbance events (see below).

There is anecdotal evidence (here and in Collar et al. 1992) that the Rufous-fronted Antthrush usually occurs only briefly (few months to $<2$ years) at any one site, suggesting that this species prefers ephemeral habitats, such as the dense understorey vegetation that invades recent disturbances. In fact, at least two territories were at the edges of very recent disturbances (lodge clearing at $1 \mathrm{~A}$ and large tree fall at $1 \mathrm{C}$ ). The other three territories were in areas where recent disturbances were indicated (dense Heliconia and small-diameter bamboo at site 2 and river-edge vegetation abutting floodplain forest at $1 B$ ); both of these sites were along outer bends of the river where erosional forces are greatest, thereby increasing disturbance. This habitat is ephemeral because, following disturbance, new vegetative growth eventually shades the immediate vicinity of the ground, and thus foliage density decreases close to the ground. Within a few years, the habitat probably becomes unsuitable for the antthrush. A territory at Manu Lodge (S. Hilty in litt. 1994), however, was occupied for at least five years, suggesting that certain conditions (man-induced?) may create relatively stable territories. The near-absence of Rufous-fronted Antthrushes in the lower portion of the Tambopata may result from a lower frequency of disturbance events because the river channel is deeper and more restricted than on the upper portion of the river.

The Rufous-fronted Antthrush may be restricted to forested margins of large rivers for two reasons. First, only large rivers may provide frequent enough disturbance to support this species. If habitat patches are only occupied for a few years, then disturbance events need to be frequent to support a population. Second, competition with other Formicarius antthrush species may restrict them to this habitat, as has been previously suggested (Parker 1983. Collar et al. 1992). The widespread Black-faced Antthrush, probably the closest relative of Rufous-fronted, is common throughout tall floodplain forest at both the ccollpa site and the EIR. Territories of this species abutted Rufous-fronted Antthrush territories $1 \mathrm{~A}$ and $1 \mathrm{C}$ in nearby floodplain forest. The other three Rufous-fronted Antthrush territories lacked extensive tall floodplain forest, and no Black-faced Antthrushes were recorded nearby. The Rufous-capped Antthrush is also sympatric with Rufous-fronted, but it is commoner on the bluff in bamboo and terre firme forest at the ccollpa. Although neither of these other species appears to prefer areas with dense understorey (pers. obs.), all three species of antthrush can occur at the same site (e.g. at Manu Lodge: S. Hilty in litt. 1994). 
All three of these Formicarius species are terrestrial and have similar diets (Table 4), giving some reason to suspect interspecific competition. They also do not differ greatly in size. The Rufous-fronted Antthrush is similar in weight to the sympatric subspecies of Black-faced Antthrush, but slightly larger than the sympatric race of Rufous-capped Antthrush (F. rufifrons male: $54 \mathrm{~g}, n=1$; female: $57 \mathrm{~g}, n=1$; F. analis analis male: $58 \mathrm{~g}, n=6$; female: $51.6 \mathrm{~g}, n=3$; . colma nigrifrons: male: $47.6 \mathrm{~g}, n=9$; female: $46.5 \mathrm{~g}, n=4$ ). The bill length of Rufous-fronted is intermediate among the three species (F. rufifrons male: 22.0 mm, female: $21.7 \mathrm{~mm}$; $F$. analis analis male: $23.8 \mathrm{~mm}$; female: $23.0 \mathrm{~mm}$; $F$. colma nigrifrons: male: $21.6 \mathrm{~mm}$; female: $21.3 \mathrm{~mm}$ ).

\section{Conservation}

The number of Rufous-fronted Antthrush territories on the Río Tambopata was calculated to be between 86 and 515. I feel that the lower estimate, using the more conservative linear measure of available habitat along the Tambopata, is closer to the real population size. Although much forest habitat identified on the satellite photograph did not abut the river (Figure 2), most forest surveyed was within $500 \mathrm{~m}$ of the river, where four of the five territories occurred. Using the less conservative area measure therefore probably overestimates the density calculated for these forests as a whole.

Within the known range of the Rufous-fronted Antthrush are seven rivers of a size expected to have appropriate habitat (equal to or larger than the Tambopata). These are, from north to south, the ríos Manu, alto Madre de Dios, Colorado, Inambari, Malinowski, Tambopata, and the lower Madre de Dios between the mouths of the Manu and Tambopata (Figure 1). Rufous-fronted Antthrushes have been found along all but the alto Madre de Dios and Malinowski (Collar et al. 1992), but are known only near the mouths of the Inambari and Colorado. The Inambari, Colorado, and Malinowski have not been recently surveyed for birds. The Manu, alto Madre de Dios, and Inambari are similar in length to the Tambopata; the lower Madre de Dios is about twice as long; the Malinowski and Colorado are about half as long. Using the Tambopata estimates of 100 or 500 territories (see above) and these estimates of river length, a global population of only 700 to 3,500 pairs is reached. Although this estimate assumes all else is equal among these rivers, habitat differences are probable between the other rivers and the Tambopata, such as were found between the upper and lower portions of the Tambopata. Unfortunately, satellite photographs were not available to analyse habitats along these other rivers.

Portions of two of these rivers are protected: the upper Río Manu is protected by Manu National Park, and the upper portion of the Tambopata (above the Malinowski east to the Bolivian border) is protected by the Tambopata/Candamo Reserve Zone (TCRZ). Although the types of land use permitted within the TCRZ have yet to be decided, river-edge habitats along the Río Tambopata above the Malinowski will most likely be protected (Foster et al. 1994, INRENA $\mathrm{ms}$ ). The Río Malinowski also falls within the TCRZ; however, the immediate river-edge habitats will probably not be protected to allow for colonization and gold-mining (INRENA ms). There has already been some colonization along 
this river. Using the estimates above, Manu National Park and the TCRZ will protect about $20 \%$ (140-700 pairs) of the entire antthrush population.

Even with these two protected areas, the increasing human population of depto. Madre de Dios may further endanger the Rufous-fronted Antthrush by fragmenting the population. In its natural state, the river-edge habitats of this species were more or less continuous, allowing Rufous-fronted Antthrushes to move among appropriate habitat patches. The increasing human population in the area up and down the river, however, poses serious threats to this continuity. Most colonization follows along the major rivers in the area. The first areas settled have been along the Madre de Dios or just upstream along major rivers. The two protected areas in the region are both far upstream along major rivers. As the river-edge areas are colonized and the habitat becomes unsuitable for antthrushes, protected and unprotected antthrush populations upstream will become isolated from one another. With such small population sizes on each river, fragmentation may pose serious threats to the stability of the populations. The lower portion of the Río Tambopata is a good example. Human colonization is proceeding upstream from the population centre of Puerto Maldonado. Almost all colonization has been immediately adjacent to the river, where colonists have cleared forest to grow crops. Colonization along the river between Puerto Maldonado and the Malinowski has led to the destruction of almost all mature forest along the river (pers. obs.), leaving almost no habitat for Rufous-fronted Antthrushes. The population in the upper Tambopata thus has been cut off from other populations of this species.

\section{Acknowledgements}

The late Ted Parker introduced me to this species at the Ccollpa de Guacamayos. My fieldwork in Peru in 1992 was made possible by Conservation International, for whom I worked in their Rapid Assessment of the TCRZ. Research in 1993 was funded by a Frank M. Chapman grant from the American Museum of Natural History, a Grants-in-Aid research award from Sigma Xi, Alexander Wetmore and AOU Council awards from the American Ornithologists' Union, and a Fugler Fellowship in Tropical Biology from the Museum of Natural Science, Louisiana State University. I thank Ing. Briceño and Rosario Acero of INRENA in Lima for permission to collect in Peru. Walter Wust helped immeasurably with securing the collecting permits. Fernando Cauper, Krista Lee, and Kathryn Deagon helped in the field. The staff of Rainforest Expeditions, headed by Eduardo Nycander, also helped in many ways with my stay in Peru. Amanda Stronza provided a copy of the pre-feasibility study. Mario Cohn-Haft helped identify stomach contents. J. V. Remsen, T. S. Schulenberg, M. Marín A., S. L. Hilty, and G. Cox made many useful criticisms of this manuscript.

\section{References}

Blake, E. R. (1957) A new species of ant-thrush from Peru. Fieldiana (Zoology) 39: 51-53. Collar, N. J., Gonzaga, L. P., Krabbe, N., Madroño Nieto, A., Naranjo, L. G., Parker, T. A., III, and Wege, D. C. (1992) Threatened birds of the Americas: the ICBP/IUCN Red 
Data Book. Third edition, part 2. Cambridge, U.K.: International Council for Bird Preservation.

Earth Observation Satellite Company (1991) Landsat thematic mapper scene \# 4329813564910809. Path 002, row 069. Color bands 3,4,5. Image date: 27 July 1991. Lanham, Maryland.

Erwin, T. L. (1984) Tambopata Reserve Zone, Madre de Dios, Peru: history and description of the reserve. Revta Peruana Entomologia 27: 1-8.

Foster, R. B., Parker, T. A., III, Gentry, A. H., Emmons, L. H., Chicchón, A., Schulenberg, T., Rodríguez, L., Lamas, G., Ortega, H., Icochea, J., Wust, W., Romo, M., Castillo, J. A., Phillips, O., Reynel, C., Kratter, A., Donahue, P. K. and Barkley, L. J. (1994) The Tambopata-Candamo Reserved Zone of southeastern Peril: a biological assessment. Washington, D.C.: Conservation International (RAP working papers 6).

INRENA [Instituto Nacional de Recursos Naturales] (1993) Conservación y desarollo sostenible en la zona reservada Tambopata-Candamo: estudio de pre-factibilidad. Unpublished report.

Parker, T. A., III, (1983) Rediscovery of the Rufous-fronted Anthrush (Formicarius rufifrons) in southeastern Peru. Gerfaut 73: 287-289.

Remsen, J. V., Jr. and Parker, T. A., III, (1983) Contribution of river-created habitats to bird species richness in Amazonia. Biotropica 15: 223-231.

\section{ANDREW W. KRATTER}

Museum of Natural Science and Department of Zoology and Physiology, Louisiana State University, Baton Ronge, LA 70803, U.S.A. 